\title{
Building a higher education learning experience strategy; theoretical and practical approaches
}

\author{
Magdalena IORDACHE-PLATIS \\ University of Bucharest, Bucharest, Romania \\ magdalena.iordache-platis@drept.unibuc.ro
}

\begin{abstract}
Higher education institutions face many challenges in order to increase their visibility, recognition and position in the field based or general higher education market. National or international rankings put a lot of pressure on academic leadership to fulfill the criteria of their methodologies. Learning experience is becoming a more and more important dimension of the motivation to study. In the contemporary context of networking diversity, the process of generating learning experience is becoming part of the institutional efforts related to which creating an internal environment is connected to the learning experience generating. The literature review proves a higher interest on student engagement, on students' and graduates' involvement in the institutional life, on development a long-term relationship between university and graduates on one hand and between university and industry on the other hand etc. The common issue among all these subjects is the learning experience that is provided to students through all the activities in higher education institutions. What can be done or develop in order to generate a great learning experience starts from a correct, but flexible understanding of the concept. What can be institutionally changed for the benefit of a higher learning experience need a clear recognition of what more experienced institutions have already achieved. The objectives of the paper include: a) a clear understanding of the learning experience concept; $b$ ) an overview of the current characteristics of the learning experience providers; c) a start-up strategy for generating learning experience. All these objectives are integrated in a literature review approach as well as in a qualitative study dedicated to the perceptions of students and academics on what learning experience means and what institutionally can be improved. The findings reveal a possible model for building up a learning experience strategy for Romanian higher education institutions.
\end{abstract}

Keywords: higher education, strategy, learning experience, rankings, academic leadership.

\section{Introduction: The new type of economy and higher education context}

Entire environment is changing, but this is not a new thing. It has always been like that: all the macroeconomic components evolve: economic, political, informational, social, legislative, environmental and cultural dimensions. Permanent changes have affected higher education institutions, from creating new study fields, and new curriculum, to new types of education and teaching methods, such as long distance or blended learning, to open access in research area and many more others. There is no doubt that the extraordinary extension of the Internet has modified the educational providers' strategies and the beneficiaries' behaviours. Sursock (2015) proved the high level of different e-learning offer among over 450 institutions at European level: blended learning courses, online courses, blended learning degree programs, online degree programmes, MOOCs, joined online learning offers, Internet being seen as a huge source of information.

The new type of economy generated from the evolution of IT\&C techniques has been recently defined as sharing economy, an economy based on online transactions. Stephany (2015) explains the new type of economy as one in which people share using special 
platforms for mutual advantage; he also states that the main characteristics of the shared economy include value, underutilized assets, online accessibility, community and reduced need for ownership. Sharing economy is also influencing higher education institutions. Young generation has always adapted very quickly to all the IT\&C challenges. Students began to type information received from traditional classes and then shared the documents among their colleagues; they began to replace when possible the reading using library facilities with online study and they started to comment on forums, discussion groups and applications sharing again the learned knowledge and even working together in teams for projects. They have easily accepted to buy online books, to download didactical materials, to get online courses etc. Students have always been more open to the sharing concept using special saving platforms, such as google drive or drop box. They have also transformed social media in useful learning tools, such as whatsapp or facebook in order to save time in the communication process with their colleagues.

Sharing economy is considered a new response to classical economy, often considered a consequence of uberization. Barreiro (2017) explains uberization as a new model for sharing economy, about connecting and not delivering, about networking effect. At the same time, Freeman (2015) describes the extension of the process of uberization being skeptical referring to its permanent success; the author shows that everything can become subject of uberization, but not every idea will succeed. In higher education institutions, the process is simply observed: educational platforms have gathered together professors and students to add knowledge to curricular programmes or to develop skills within extra-curricular programmes, such as entrepreneurial ones. In addition, other interested parties, such as companies become part through the platforms to the sharing process.

In the sharing economy context, students share knowledge, perceptions, impressions, emotions, feelings and influence other colleagues in a way or another. At the same time, they also share experiences in the dialog with potential new entrants. Learning experience is shared, trust, accepted as a motivational criterion, or ignored and forgotten. Strategies are adopted by higher education institutions to provide proper learning experiences to their students. A different understanding of the concept leads to different strategies in providing learning experience. Bratianu \& Bolisani (2015) explain the matrix of generic knowledge strategies which includes knowledge sharing; they show that it is generated from the combination of two variables: organizational knowledge which is known and awareness which is not known. Academic leadership is responsible of the decision-making process related to the investment in learning experience. In fact, the entire quality of teaching and learning is directly connected to the quality of the learning experience. Gover et al. (2015) show that institutions have the obligation of providing fair and transparent procedures to students beginning with the admission process, obligation with direct consequences on learning experience.

The purpose of the paper is to provide a clear understanding of the learning experience concept in order to provide a model for building up a strategy of learning experience in higher education. The concept is going to be clarified on a literature review basis, as well as on a revision of institutional methodologies followed by either universities 
or ranking systems. The construction of the model is based on the perceptions of students and academics on learning experience, and also their common view on this matter.

\section{Literature review: learning experience and strategies adopted Understanding the learning experience concept}

The concept of learning experience is neither a new, nor an unanimously accepted one. A broad meaning of learning experience is provided by the Glossary of Education Reform (2013) where learning experience is explained through both traditional settings, such as classrooms and facilities and nontraditional settings, such as locations outside university buildings, and also through both classical professor-student interactions and modern interactions, generated in the process of software applications usage.

Another way of understanding learning experience is generated from the connection of the two words: 'learning' and 'experience'. McCluskey (2009) explains 'learning' by all situations people can learn from, no matter if these are explicit and formal or not and 'experience' by any contact with the world; therefore, he states that 'learning experience' is any event or activity defined by 'learning by experience', meaning knowledge that is generated from experience with the world.

Nevertheless, there is a common view among students, academic staff and quality managers according to Greere and Riley (2014) which shows that quality in higher education is primary determined by the teaching and learning experience. They also state that there is a set of contributing factors of learning experience to be also considered: a close student-professor relationship, a feedback constantly exchanged, both sides motivation, dynamism in teaching methodologies, professional transfer of knowledge, competence development, adapted programmes to market needs, proper resources, facilities and infrastructure, student services, effective communication etc.

A more general approach of learning experience takes into consideration any action the academic leadership is managed in order to make their students to most benefit from the available resources. Gibbs (in Brusoni et al., 2014, p. 12) explains the features for a positive learning experience in relationship with what institutions do with their resources, to provide well understood pedagogical practices that engender student engagement; he also mentions that learning experience does not mean facilities or students' satisfaction related to these. In addition, Elton (in Brusoni et al., 2014, p. 13) explains that a necessary condition, even if not sufficient for an excellent student learning experience is an individual teaching excellence.

\section{Learning experience - institutional considerations}

The concept of learning experience is used in different practical context, such as internal documents - strategies, operational plans, or methodologies. Learning experience can be observed in the activity of several rankings or ranking-related institutions or in different higher education institutions. Table 1 and 2 reveal some of the conceptual integrations into their current activities.

Table 1. Learning experience in the activity of ranking-related institutions

\begin{tabular}{|l|l|l|l|l} 
No. & Ranking/institution & No of results & Relevant conceptual & Comments \\
\hline
\end{tabular}

DOI: $10.2478 /$ picbe-2018-0044,pp. 486-497, ISSN 2558-9652| Proceedings of the $12^{\text {th }}$ International Conference on Business Excellence 2018 


\begin{tabular}{|c|c|c|c|c|}
\hline & and source & $\begin{array}{l}\text { matching } \\
\text { 'learning } \\
\text { experience' on } \\
\text { web searching }\end{array}$ & integrations & \\
\hline 1. & $\begin{array}{l}\text { Academic Ranking of } \\
\text { World Universities } \\
\text { http://www.shanghai } \\
\text { ranking.com/ARWU20 } \\
\text { 17.html }\end{array}$ & $\begin{array}{l}\text { No matches } \\
\text { found }\end{array}$ & $\begin{array}{l}\text { The focus is not on } \\
\text { learning experience. } \\
\text { The ranking consider } \\
\text { alumni results in } \\
\text { correlation to their } \\
\text { academic and research } \\
\text { performance. }\end{array}$ & $\begin{array}{l}\text { Indicators refer to academic or } \\
\text { research performance, such as } \\
\text { alumni and staff winning } \\
\text { Nobel Prizes and Fields } \\
\text { Medals, highly cited } \\
\text { researchers, papers indexed in } \\
\text { major citation indices. }\end{array}$ \\
\hline 2. & $\begin{array}{l}\text { U-multirank - subject } \\
\text { based } \\
\text { https://www.umultira } \\
\text { nk.org/\#!/about/meth } \\
\text { odology/data- } \\
\text { sources?trackType=ab } \\
\text { out\&sightMode=undef } \\
\text { ined\&section=undefin } \\
\text { ed }\end{array}$ & Not available & $\begin{array}{l}\text { Overall learning } \\
\text { experience is one } \\
\text { criterion integrated in } \\
\text { the teaching and } \\
\text { learning dimension, } \\
\text { together with contact } \\
\text { with work } \\
\text { environment, quality of } \\
\text { courses and teaching, } \\
\text { organization of } \\
\text { program, library } \\
\text { facilities, IT provision, } \\
\text { contact with teachers. }\end{array}$ & $\begin{array}{l}\text { Teaching and learning } \\
\text { dimension is based on } \\
\text { students' view. In } 2017 \text {, the } \\
\text { students' survey was based on } \\
\text { more than } 100,000 \text { responses. }\end{array}$ \\
\hline 3. & $\begin{array}{l}\text { THE World University } \\
\text { Rankings } \\
\text { https://www.timeshig } \\
\text { hereducation.com/stu } \\
\text { dent/news/student- } \\
\text { experience-survey- } \\
\text { 2017-results }\end{array}$ & 13,682 & $\begin{array}{l}\text { A survey is annually } \\
\text { conducted: The Student } \\
\text { Experience Survey } \\
\text { where a general score } \\
\text { is published. }\end{array}$ & $\begin{array}{l}\text { In } 2017 \text { it was the } 10^{\text {th }} \text { release } \\
\text { got from around } 15,000 \\
\text { respondents on: academic } \\
\text { experience, university } \\
\text { facilities, societal experience, } \\
\text { student welfare, } \\
\text { accommodation, industry } \\
\text { connections, security, student } \\
\text { unions. }\end{array}$ \\
\hline 4. & $\begin{array}{l}\text { Global Fashion School } \\
\text { Ranking } \\
\text { https://www.business } \\
\text { offashion. } \\
\text { com/education/ranki } \\
\text { ngs/2017 }\end{array}$ & 99 & $\begin{array}{l}\text { Learning experience is } \\
\text { an important criterion } \\
\text { among others: global } \\
\text { influence and long-term } \\
\text { value. }\end{array}$ & $\begin{array}{l}\text { Learning experience is based } \\
\text { on a feedback on quality of } \\
\text { teaching and resources in the } \\
\text { institution. }\end{array}$ \\
\hline
\end{tabular}

Source: Author's own research.

Rankings pay more or less attention to learning experience, as a clear and direct concept, such as a criterion of ranking. There are rankings, where a huge focus is put on research production, but in such an institutional context, a proper research environment is a great opportunity for students to learn. Other rankings integrate in their dimensions results of student survey expressing their perceptions on the learning environment. In most of the cases, learning experience is connected to the quality of teaching in the institution.

Table 2. Learning experience in the activity of different higher education institutions

\begin{tabular}{|l|l|l|l|l|}
\hline $\begin{array}{l}\text { Crt. } \\
\text { No. }\end{array}$ & University & $\begin{array}{l}\text { No of results } \\
\text { matching } \\
\text { Iearning }\end{array}$ & $\begin{array}{l}\text { Relevant conceptual } \\
\text { integrations }\end{array}$ & Comments \\
\hline
\end{tabular}

DOI: $10.2478 /$ picbe-2018-0044, pp. 486-497, ISSN 2558-9652| Proceedings of the $12^{\text {th }}$ International Conference on Business Excellence 2018 


\begin{tabular}{|c|c|c|c|c|}
\hline & & $\begin{array}{l}\text { experience' } \\
\text { on web } \\
\text { searching }\end{array}$ & & \\
\hline 1. & $\begin{array}{l}\text { Harvard University } \\
\text { https://www.harva } \\
\text { rd.edu/ }\end{array}$ & 51,900 & $\begin{array}{l}\text { Caila - Anyone's Learning } \\
\text { Experience is a career } \\
\text { concierge - personalized } \\
\text { learning for individuals; } \\
\text { Experience vs. learning; } \\
\text { An event: Learning spaces } \\
\text { week - generate learning } \\
\text { experiences (explore } \\
\text { campus, get ideas) }\end{array}$ & $\begin{array}{l}\text { Learning experience is } \\
\text { related to sharing, } \\
\text { either it is about } \\
\text { counseling, meaning } \\
\text { the transfer of } \\
\text { knowledge and } \\
\text { experiences from an } \\
\text { experimented } \\
\text { individual to students, } \\
\text { or about sharing best } \\
\text { practices through } \\
\text { different actions and } \\
\text { events. }\end{array}$ \\
\hline 2. & $\begin{array}{l}\text { Standford } \\
\text { University } \\
\text { https://www.stanfo } \\
\text { rd.edu/ }\end{array}$ & 54,900 & $\begin{array}{l}\text { Learning experiences are } \\
\text { designed using design; } \\
\text { A startup is a learning } \\
\text { experience; } \\
\text { Learning platforms are } \\
\text { offered by partners; } \\
\text { Peer learning - sharing ideas, } \\
\text { knowledge and experiences } \\
\text { among participants, } \\
\text { A two stage exam is a learning } \\
\text { experience (individual and } \\
\text { small group evaluations) etc. }\end{array}$ & $\begin{array}{l}\text { Learning experience is } \\
\text { related to the usage of } \\
\text { TIC in different } \\
\text { activities, either } \\
\text { through dedicated } \\
\text { platforms, or to simple } \\
\text { informational purpose } \\
\text { of different web pages } \\
\text { where articles are } \\
\text { shared. }\end{array}$ \\
\hline 3. & $\begin{array}{l}\text { University of } \\
\text { Cambridge } \\
\text { http://www.cam.ac. } \\
\text { uk/ }\end{array}$ & 33,676 & $\begin{array}{l}\text { Student-doctors experience } \\
\text { learning communication in } \\
\text { clinical learning environment; } \\
\text { Diversity in class makes a } \\
\text { powerful learning experience; } \\
\text { Enterprises provide an } \\
\text { inspirational learning } \\
\text { experience; } \\
\text { Sharing experiences of } \\
\text { learning etc. }\end{array}$ & $\begin{array}{l}\text { Learning experience is } \\
\text { more understood as a } \\
\text { set of teaching and } \\
\text { learning methods - } \\
\text { mainly as diversity in } \\
\text { teaching methods and } \\
\text { different leaning } \\
\text { environment. }\end{array}$ \\
\hline 4. & $\begin{array}{l}\text { Babes-Bolyai } \\
\text { University } \\
\text { http://www.ubbcluj } \\
\text {.ro/ro/ }\end{array}$ & 6 & $\begin{array}{l}\text { Statement related to quality in } \\
\text { the university; } \\
\text { Principles, criteria and } \\
\text { indicators of quality assurance }\end{array}$ & $\begin{array}{l}\text { Learning experience is } \\
\text { more integrated in } \\
\text { documents, having a } \\
\text { declarative state. }\end{array}$ \\
\hline
\end{tabular}

PICBE | 490

Source: Author's own research.

Higher education institutions integrated the concept of learning activity in their daily life in what and how they do the transfer of knowledge, ideas, practices - from special facilities and spaces, meaning that investment had taken place, to any kind of non-physical source of learning experience. Bratianu \& Vatamanescu (2017) studied the students' perceptions in the process of developing generic skills and concluded that the change from the traditional way of knowledge transfer to the more developing generic thinking skills means in fact an important change in the entire process of teaching. 
Therefore, there is no doubt that learning experience is linked to the teaching process, as learning goes along with teaching in an integrated process in the formal context of a higher education institution. But this is only one side of the concept, the classical one. The trend in learning experience understanding is towards any action related to sharing experiences from one to another and all possibilities of increasing this sharing efficiency.

\section{Methodology: Academics' and students' perceptions on learning experience}

In higher education institutions, academic leadership has a major role in more than taking proper decisions in concordance with the institutional mission; it's role is more important when implementation phase is run. Hwang (2015) explained the role of academic leadership and the importance of creating a learning environment; he states that a creative learning environment is at the very centre, along with a closer relationship between educational programmes and external parties. In fact, any type of student-related service provided in the higher education institution impacts the student learning and his or her success. Ciobanu (2013) conducted a study revealing that student services increase the student learning experience by controlling the drop out and diminishing it, improving the life diversity, increasing quality of learning, preparing students for effective involvement in the society etc. In addition, students are considered real partners in defining strategies and in the decision making process within higher education institutions. One of the European standard for quality assurance in higher education area is related to the 'student-centred learning, teaching and assessment', meaning that institutional programmes should be offered in a way that students be able to adopt an active role in creating learning process and the assessment of the students should consider this role. The accent is put on teaching diversity, on different teaching methods, on flexible learning paths, on student autonomy in choosing a learning way etc.

Therefore, no important decision is effective until interested parties cooperate and work together in the implementation process. Building a strategy for learning experience requires such a common intervention of academics and leaders on one hand, and of students, on the other hand. Lacerda et al. (2014) describe the multifactorial influences on strategy implementation in higher education institutions and identify different correlations among factors.

The research conducted at the University of Bucharest is based on a two phases questionnaire based on open questions (phase 1) and value of agreement of different statements (phase 2) related to learning experience. Both sets of questions were addressed to two respondents: academics and academic leaders, as first group and students at undergraduate and graduate level of studies, as the second group.

First phase revealed the common understanding of the respondents on the question what do you understand by 'learning experience'. Some of the responses explain 'learning experience' as the following expressions:

- An environment that is friendly equipped for young generation;

- Many and different types of rooms, with intelligent devices and all over internet; 
- A continuous dialog-based relationship professors-students,

- A teaching style and method that is based on interactions and open questions and answers;

- A proper investment in library - computers, books, journals etc up to date;

- Internet everywhere;

- Teaching methods that connects theory to practice;

- Specialists from industries come to classes;

- Students are allowed to work in campus or halls of residence;

- All kinds of events that contribute to personal development;

- Professors are models for students;

- An environment with well-trained professors and high technologies;

- An environment where students can learn and become interested in their study subject;

- An inspirational environment etc.

Table 3 reveals the main responses where the essence of the message is simplified and integrated in one group's or both groups' messages:

Table 3. Understanding learning experience - academics'/leaders' and students' thoughts

\begin{tabular}{|l|l|c|c|c|}
\hline $\begin{array}{l}\text { Crt. } \\
\text { No. }\end{array}$ & $\begin{array}{l}\text { Learning experience } \\
\text { understanding }\end{array}$ & $\begin{array}{l}\text { Academics } \\
\text { leaders }\end{array}$ & Students & $\begin{array}{l}\text { Common } \\
\text { understanding }\end{array}$ \\
\hline 1. & Proper equipment & $\checkmark$ & & \\
\hline 2. & Enough rooms & $\checkmark$ & & \\
\hline 3. & Financial resources & $\checkmark$ & $\checkmark$ & $\checkmark$ \\
\hline 4. & Excellent professors & $\checkmark$ & $\checkmark$ & $\checkmark$ \\
\hline 5. & Internet available everywhere & $\checkmark$ & & \\
\hline 6. & Library facilities & $\checkmark$ & $\checkmark$ & $\checkmark$ \\
\hline 7. & $\begin{array}{l}\text { Great relationship professors- } \\
\text { students }\end{array}$ & & $\checkmark$ & $\checkmark$ \\
\hline 8. & More practice than theory & & $\checkmark$ & \\
\hline 9. & Living experiences & & $\checkmark$ & \\
\hline 10. & Learning by doing & & & \\
\hline
\end{tabular}

Source: Author's own research.

Higher education institutions integrated the concept of learning activity in their daily life in what and how they do the transfer of knowledge, ideas, practices - from special facilities and spaces, meaning that investment had taken place, to any kind of non-physical source of learning experience.

The common understanding of 'learning experience' is related to three main areas, considering both responses of academics/leaders and students integrated and correlated:

- Excellent teaching - meaning well-trained professors, good relationship with students, interactive teaching, leas theory and more practical issues to be taught or experiences;

- Proper equipped rooms - meaning mainly interned available. Some differences have been noticed, professors meaning through proper equipment more than interned everywhere.

On one hand, academics/leaders group understands by 'learning experience' an environment where they can act properly, having all material and financial resources 
available.; together with their expertise, all resources will be used to generate learning opportunities to students. On the other hand, students' group believe that 'learning experience' is more than learning from excellent professors in excellent material conditions, they understand the opportunity of leaning through acting, being involved in activities for the academic community, including opportunities generating living experiences. Figure 1 reveal the groups understandings.

Therefore, there is no doubt that learning experience is linked to the teaching process, as learning goes along with teaching in an integrated process in the formal context of a higher education institution. But this is only one side of the concept, the classical one. The trend in learning experience understanding is towards any action related to sharing experiences from one to another and all possibilities of increasing this sharing efficiency. Sharing has not been properly mentioned during the first phase of the research, on an open question basis.

In the second phase, 58 valid questionnaires were collected from academics and 120 from students; a Likert scale was used and score were calculated. Questions were generated from both literature review and previous perceptions on learning experience.

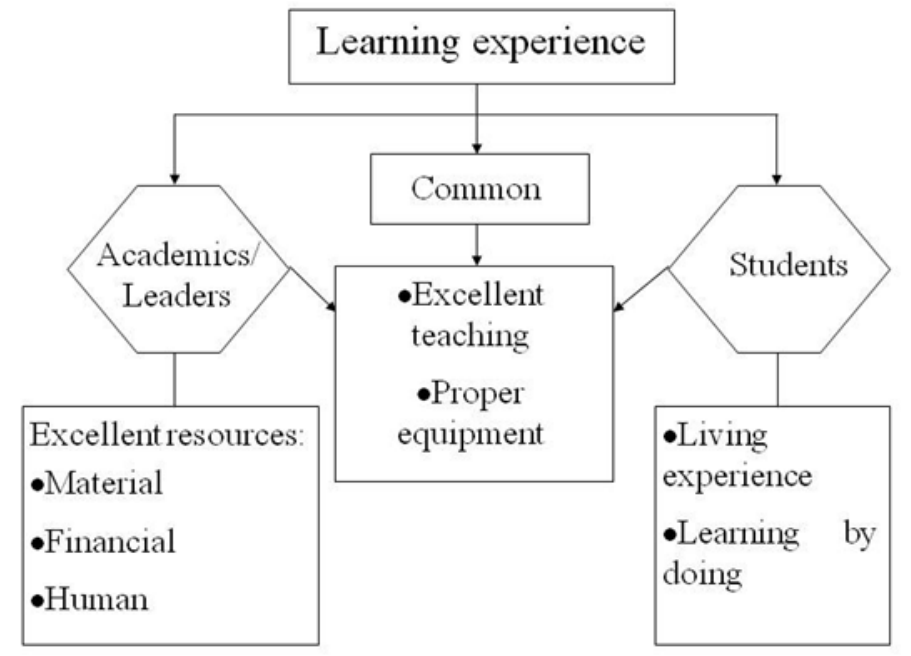

Figure 1. Understanding learning experience

Source: Author's own research.

The distribution of the respondents is described in Table 4. and Table 5.

Table 4. Distribution of the respondents - students

\begin{tabular}{|l|l|l|l|}
\hline Level of study/ Structure & Female & Male & Total \\
\hline Undergraduate level & 46 & 40 & 86 \\
\hline Graduate level & 22 & 12 & 34 \\
\hline Total & 68 & 52 & 120 \\
\hline
\end{tabular}

Table 5. Distribution of the respondents - academics/leaders

\begin{tabular}{|l|l|c|l|}
\hline Academic position & Female & Male & Total \\
\hline Assistants and lecturers & 21 & 14 & 35 \\
\hline Associate professors and & 16 & 7 & 23 \\
\hline
\end{tabular}




\begin{tabular}{|l|l|l|l|}
\hline professors & & & \\
\hline Total & 37 & 21 & 58 \\
\hline
\end{tabular}

The responses are revealed in Table 6.

Table 6. Learning experience understanding - academics/leaders' and students' perceptions

\begin{tabular}{|c|c|c|c|}
\hline $\begin{array}{l}\text { Crt. } \\
\text { No. }\end{array}$ & Question/Sentence & $\begin{array}{l}\text { Likert score - } \\
\text { students }\end{array}$ & $\begin{array}{l}\text { Likert score- } \\
\text { academics/leaders }\end{array}$ \\
\hline 1. & $\begin{array}{l}\text { Learning experience is related to sharing: } \\
\text { counseling, transfer of knowledge and } \\
\text { experiences, best practices etc. }\end{array}$ & 4.07 & 3.03 \\
\hline 2. & $\begin{array}{l}\text { Learning experience is related to the TIC } \\
\text { integration into different activities: } \\
\text { platforms, web pages, forums etc. }\end{array}$ & 2.88 & 3.69 \\
\hline 3. & $\begin{array}{l}\text { Learning experience is more understood as a } \\
\text { set of teaching and learning methods - } \\
\text { mainly as diversity in teaching methods. }\end{array}$ & 3.93 & 3.50 \\
\hline 4. & $\begin{array}{l}\text { Learning experience does not exist } \\
\text { effectively, it is more integrated in } \\
\text { documents, having a declarative state. }\end{array}$ & 3.68 & 3.67 \\
\hline 5. & $\begin{array}{l}\text { Learning experience means available } \\
\text { resources to institutionally develop different } \\
\text { actions/projects. }\end{array}$ & 2.88 & 3.69 \\
\hline 6. & $\begin{array}{l}\text { Learning experience is more } \\
\text { relationships about } \\
\text { equipment. }\end{array}$ & 3.45 & 4.69 \\
\hline 7. & $\begin{array}{l}\text { Learning experience is an individual living } \\
\text { experience that may differ from one student } \\
\text { to another. }\end{array}$ & 3.91 & 2.12 \\
\hline 8. & $\begin{array}{l}\text { Learning experience is about learning, no } \\
\text { matter how. }\end{array}$ & 2.15 & 2.55 \\
\hline 9. & $\begin{array}{l}\text { Learning experience is about learning, but in } \\
\text { a friendly environment. }\end{array}$ & 4.02 & 4.02 \\
\hline
\end{tabular}

Source: Author's own research.

Therefore, both groups agree and totally agree on the following learning experience understanding: it means sharing and knowledge transfer, it is related to teaching methods, it is more related to relationships than equipment, it means learning but not anyhow, only in a friendly environment. In addition, both groups agree that at present, learning experience is a more theoretical concept, used in institutional documents.

Many things can be done in order to develop a learning environment towards a learning experience for students and graduates. When decisions are made without a proper understanding among people that contribute to the implementation strategy, results are poor. Berg (2012) explain that an important step in achieving a successful strategy implementation is the engagement of both employers and stakeholders; he also states that this engagement is more than strategy understanding, it has to do with preparation, integration, communication and clarification among all interested parties. In higher education institutions, building a learning experience strategy should start from what academics and students already understand and improve their knowledge, and then their actions and engagement. 


\section{Results and discussions}

Building a strategy of learning experience is a process that takes time being very much related to quality assurance in all kind of activities. The phases in building up a strategy are very much discussed in the management literature. Meyers (2014) explains three strategies of creating learning experiences that are relevant for higher education process: assessing early and often, involving students in activities such as problem-based learning or involvement in the community learning, and encouraging students to provide feedback on content and assignment. Edinger (2012) shows that there are three steps in the process of building a strategy, called three "Cs": clarification, communication and cascade the strategy; he states that implementation can become a source of competitive advantage.

Therefore, a learning experience strategy can be built as shown in Figure 2.

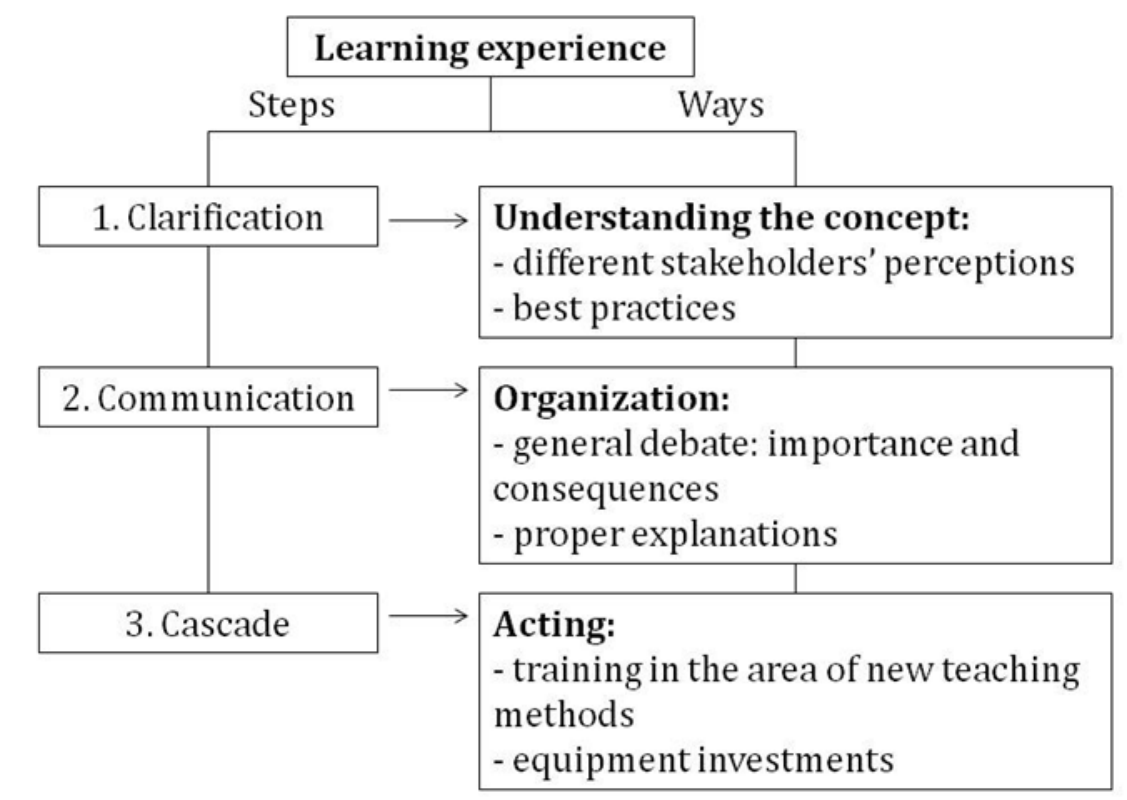

Figure 2. Building a learning experience in higher education institutions

Source: Author's own research.

Learning experience strategy starts from clarification of it. It is a phase based on proper understanding of the concept and of the ways that implementation can take place. Once the understanding of the learning strategy is clear - good teaching, friendly environment, sharing of knowledge and experiences in every way, etc., ways of implementing it should be also shared from one team to another, from one group of students to another. The ways might include an investment into new teaching methods, practice sharing, experiential teaching, equipment investment etc. In other words, communication is related to organization towards implementation. The last step is cascade, when strategy, meaning ways of acting are more shared through conferences, debates and effective new relationships with students. 


\section{Conclusion}

This paper is an interesting proposition of what is learning experience and how it is currently understood by academics/leaders and students in lack of resources context. The importance of the work is based on the usefulness of the common understanding which is considered a starting point in the developing process of the learning experience strategy. Main contributions of the paper are: the literature review on the concept of learning experience, best practices in using this concept, from ranking institutions to higher education institutions, identifying the academics'/leaders' and students' perceptions on learning experiences and a model for building up such a strategy. The importance of the work is based on the relevance of a learning experience strategy on quality assurance mechanisms in higher education institutions. Graduates, as former students will feel that they belong to the alumni group and they will act like that only if they have had a learning experience during their studies. In other words, building up a learning experience strategy will consolidate the transfer of students as graduates into involved alumni.

Possible extensions of the research may include how current alumni describe their learning experience in order to adjust the strategy, and what kind of emotional capital component were strengthened during studies and which were not, such as attachment, resilience, optimism, self-esteem etc.

Major limitations are generated from the small number of the respondents in both groups and from the difference between theoretical and practical recognition approaches when respondents replied. They might have considered the responses in defining learning experience in terms of theoretical approach and not based on their experience, while some others did the opposite. In other words, many of the respondents might know more about what learning experience is than the results proved, simply because the process of developing it is much more behind the theoretical and conceptual clarifications of it.

\section{References}

Barreiro, E. (2017). Uberization? It's about connecting, not deliveing. Retrieved from http://www.supplychain247.com/article/uberization_its_about_connecting_not_deli vering.

Berg, R. (2012). 5 Steps to successful strategy implementation. Retrieved from http://bergconsulting.com.au/Berg_Consulting_Blog/5-essential-steps-tosuccessful-strategy-implementation.

Bratianu, C. and Bolisani, E. (2015). Knowledge strategy: an integrated approach for managing uncertainty. In Massaro, M. and Garlatti, A. (Eds.). Proceedings of the $16^{\text {th }}$ European Conference on Knowledge Management, University of Udine, Italy, 3-4 September 2015 (pp. 169-177). Reading: Academic Conferences and publishing International.

Bratianu, C. and Vatamanescu, E.M. (2017). Students' perception on developing conceptual generic skills for business: a knowledge-based approach. VINE Journal of Information and Knowledge Management Systems, Vol. 47, Issue 4, pp. 490-505.

Brusoni, M. et al. (2014). The concept of excellence in higher education. Retrieved from http://www.enqa.eu/indirme/papers-and-reports/occasional- 
papers/ENQA\%20Excellence\%20WG\%20Report_The\%20Concept\%20of\%20Excell ence $\% 20 \mathrm{in} \% 20$ Higher\%20Education.pdf.

Ciobanu, A., (2013). The role of student services in the improving of student experience in higher education, Procedia - Social and Behavioral Sciences 92 ( 2013 ) 169 - 173.

Retrieved from https://ac.els-cdn.com/S1877042813027857/1-s2.0S1877042813027857-main.pdf?_tid=93f9510c-f310-11e7-8086-

PICBE $\mid 497$ 00000aab0f6b\&acdnat=1515263998_8f20257469145986456b7e4ff0d42902.

Edinger, S. (2012). Three Cs of implementing strategy. Retrieved from https://www.forbes.com/sites/scottedinger/2012/08/07/three-cs-ofimplementing-strategy/\#49ecff905fb1.

ENQA, (2015). European Standards and Guidelines for Quality Assurance in the European Higher Education Area (ESG). Retreived from http://www.enqa.eu/wpcontent/uploads/2015/11/ESG_2015.pdf

Freeman, S. (2015). 'Uberization' of everything is happening, but not every 'Uber' will succeed. Retrieved from http://www.huffingtonpost.ca/2015/04/01/uberizationuber-of-everything_n_6971752.html.

Gover, A., Loukkola, T., \& Sursok, A. (2015). ESG Part 1: Are universities ready? Retrieved from http://www.eua.be/Libraries/publications-homepagelist/eua_occ_papers_esg_web.pdf?sfvrsn=4.

Greere, A., \& Riley, C. (2014). Engagement, empowerment, ownership - How to nurture the quality culture in higher education. Working together to take quality forward (p. 39). Retrieved from http://www.enqa.eu/indirme/papers-and-reports/occasionalpapers/EUA_EQAF_Publication_web-1.pdf.

Hwang, S. (2015). Interview in University leaders' perspectives. Governance and funding (p. 25). Retrieved from http://www.eua.be/Libraries/publications-homepagelist/university-leaders'-perspectives-governance-and-funding.pdf?sfvrsn=2.

Lacerda, D., P., Caulliraux, H., M., Spiegel, T. (2014). Revealing factors affectimg strategy implementation in HEIs - a case study in a Brazilian university. International Journal of Management in Education. Retrieved from http://www.gmap.unisinos.br/enGB/publications/journal-articles/400-revealing-factors-affecting-strategyimplementation-in-heis-a-case-study-in-a-brazilian-university.

McCluskey, A. (2009). Tracing out learning experiences. Retrieved from http://www.connected.org/learn/Learning-experiences.html.

Meyers, S. (2014). Three strategies for creating meaningful learning experiences. Retrieved from https://www.facultyfocus.com/articles/effective-teaching-strategies/threestrategies-creating-meaningful-learning-experiences/

Sursock, A. (2015). Trends 2015: Learning and teaching in European universities. Retrieved from http://www.eua.be/Libraries/publications-homepagelist/EUA_Trends_2015_web.pdf?sfvrsn=18.

Stephany, A. (2015). The business of sharing. Hampshire, Palgrave Macmillan.

The Glossary of Education Reform (2013). Learning experience. Retrieved from http://edglossary.org/learning-experience/. 